\title{
Qualitative and Quantitative Aspects of the Microanatomy of the African Elephant Cerebellar Cortex
}

\author{
Busisiwe C. Maseko ${ }^{a}$ Bob Jacobs ${ }^{b}$ Muhammad A. Spocter ${ }^{a, c, d}$ \\ Chet C. Sherwood ${ }^{d}$ Patrick R. Hof ${ }^{e}$ Paul R. Manger ${ }^{a}$ \\ a School of Anatomical Sciences, Faculty of Health Sciences, University of the Witwatersrand, \\ Johannesburg, Republic of South Africa; ' Laboratory of Quantitative Neuromorphology, Psychology, \\ Colorado College, Colorado Springs, Colo., 'Department of Anatomy, Des Moines University, Des Moines, lowa, \\ ${ }^{\mathrm{d}}$ Department of Anthropology, The George Washington University, Washington, D.C., and e Fishberg Department \\ of Neuroscience and Friedman Brain Institute, Mount Sinai School of Medicine, New York, N.Y., USA
}

\section{Key Words}

Elephant · Cerebellum • Cerebellar cortex · Proboscidae •

Brain evolution $\cdot$ Mammalia

\begin{abstract}
The current study provides a number of novel observations on the organization and structure of the cerebellar cortex of the African elephant by using a combination of basic neuroanatomical and immunohistochemical stains with Golgi and stereologic analysis. While the majority of our observations indicate that the cerebellar cortex of the African elephant is comparable to other mammalian species, several features were unique to the elephant. The three-layered organization of the cerebellar cortex, the neuronal types and some aspects of the expression of calcium-binding proteins were common to a broad range of mammalian species. The Lugaro neurons observed in the elephant were greatly enlarged in comparison to those of other large-brained mammals, suggesting a possible alteration in the processing of neural information in the elephant cerebellar cortex. Analysis of Golgi impregnations indicated that the dendritic complexity
\end{abstract}

of the different interneuron types was higher in elephants than other mammals. Expression of parvalbumin in the parallel fibers and calbindin expressed in the stellate and basket cells also suggested changes in the elephant cerebellar neuronal circuitry. The stereologic analysis confirmed and extended previous observations by demonstrating that neuronal density is low in the elephant cerebellar cortex, providing for a larger volume fraction of the neuropil. With previous results indicating that the elephants have the largest relative cerebellar size amongst mammals, and one of the absolutely largest mammalian cerebella, the current observations suggest that the elephants have a greater volume of a potentially more complexly organized cerebellar cortex compared to other mammals. This quantitatively larger and more complex cerebellar cortex likely represents part of the neural machinery required to control the complex motor patterns involved in movement of the trunk and the production of infrasonic vocalizations.

\begin{tabular}{ll}
\hline KARGER & (c) 2012 S. Karger AG, Basel \\
0006-8977/13/0811-0040\$38.00/0 \\
$\begin{array}{l}\text { Fax +4161306 1234 } \\
\begin{array}{l}\text { E-Mail karger@karger.ch } \\
\text { www.karger.com }\end{array}\end{array}$ & $\begin{array}{l}\text { Accessible online at: } \\
\text { www.karger.com/bbe }\end{array}$
\end{tabular}




\section{Introduction}

In their review of the structure of the elephant brain, Cozzi et al. [2001] indicate that the cerebellar cortex in elephants possesses the same basic structure as that of other mammals, being divided into three main layers: the molecular layer, the Purkinje cell layer and the granule cell layer [Obersteiner, 1913; Lange, 1971, 1975; Mann and Yates, 1979]. In all mammals studied to date, the molecular layer is the most superficial and consists of Purkinje cell dendrites, myelinated and unmyelinated axons, stellate cells and basket cells [Dvergsten et al., 1984]. The Purkinje cell layer lies deep to the molecular layer and is comprised of one layer of large, pear-shaped Purkinje cell somata with very extensive spiny dendritic arborizations, reaching into the molecular layer [Palay and Chan-Palay, 1974]. Deep to the Purkinje cell layer is the granule cell layer, which contains densely packed granule cells, Lugaro cells, Golgi cells and unipolar brush cells [Palay and Chan-Palay, 1974; Lainé and Axelrad, 2002]. The underlying white matter contains the axons of Purkinje cells, mossy fibers, climbing fibers and the deep cerebellar nuclei [Palay and Chan-Palay, 1974].

The density of cells in the cerebellar cortical layers has been shown to differ across species such that brains with smaller mass tend to possess a greater density of cells per unit volume [Lange, 1975]. For instance, in one study the granule layer of the elephant was reported to have the lowest neuronal density $\left(807\right.$ cells per $\left.0.001 \mathrm{~mm}^{3}\right)$, followed by the rhesus monkey (2,099 cells per $\left.0.001 \mathrm{~mm}^{3}\right)$, and the highest neuronal density reported in the rat $(3,216$ cells per $0.001 \mathrm{~mm}^{3}$ ) [Lange, 1975]. In the Purkinje layer, with respect to sizes of individual Purkinje cell soma, elephants had the largest somas, followed by rhesus monkeys, with rats having the smallest somas; however, the granule cell layer showed no significant species differences in soma size [Lange, 1975].

It is thus clear that the elephant cerebellar cortex is typically mammalian in general laminar architecture; however, prior studies have not examined neuronal morphology or neurochemical phenotypes of cells in any detail. Due to the fact that tissue suitable for immunohistochemical analysis is now available [Manger et al., 2009] and that elephants possess the largest relative cerebellar size of all mammals [Maseko et al., 2012] (fig. 1), the present study explores the fine structure of the African elephant (Loxodonta africana) cerebellar cortex by using immunohistochemistry and Golgi staining to characterize its anatomy more fully. Moreover, given the seemingly uniform structure of the cerebellar

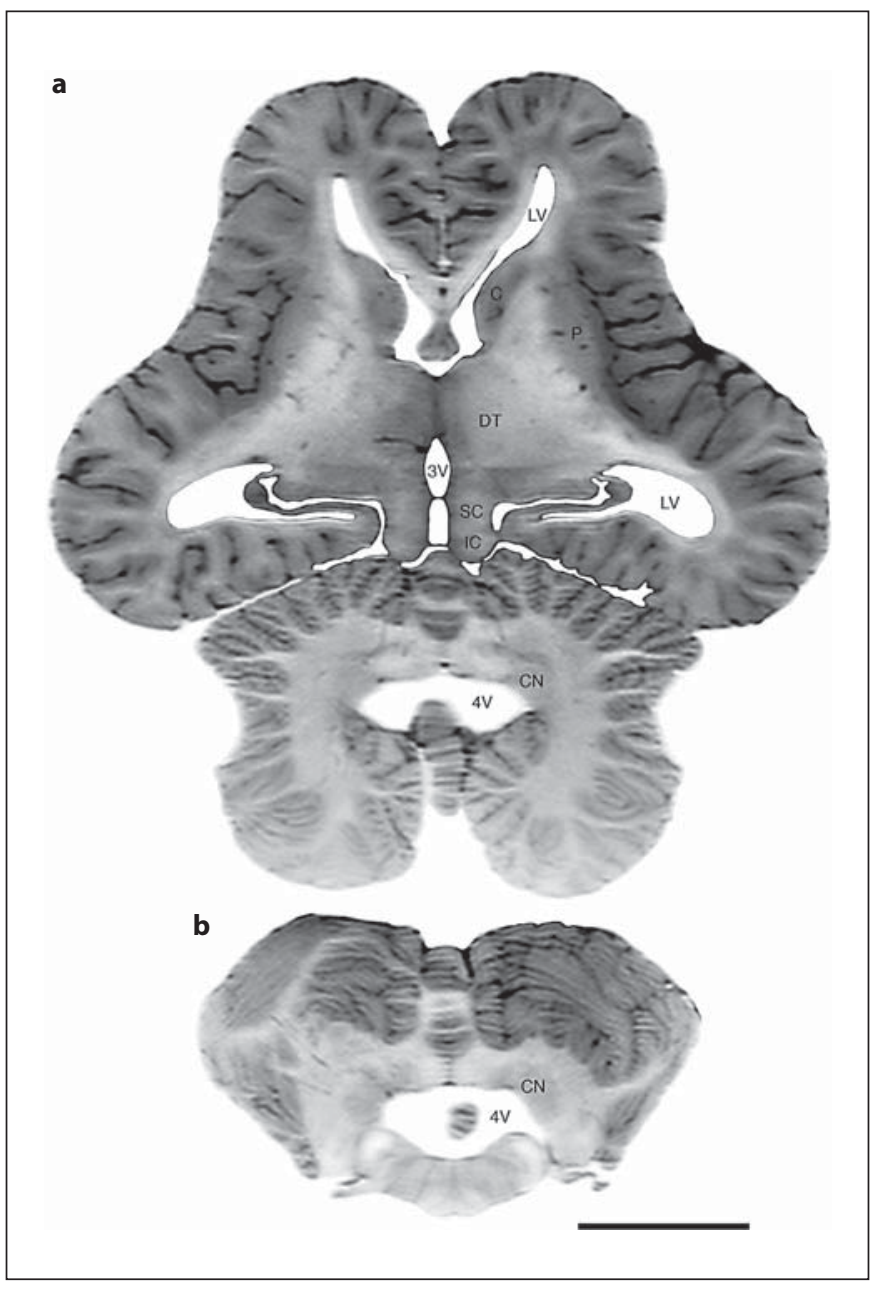

Fig. 1. MRI sections of the elephant brain showing the size and relationships of the cerebellum in a horizontal plane (a) and a coronal plane (b). Note the relatively large size of the elephant cerebellum. Scale bar $=5 \mathrm{~cm} .3 \mathrm{~V}=$ Third ventricle; $4 \mathrm{~V}=$ fourth ventricle; $\mathrm{C}=$ head of caudate nucleus; $\mathrm{CN}=$ deep cerebellar nuclei; DT = dorsal thalamus; IC = inferior colliculus; $\mathrm{LV}=$ lateral ventricle; $\mathrm{P}=$ putamen nucleus; $\mathrm{SC}=$ superior colliculus.

circuitry, the question arises as to whether the mammal with the largest relative cerebellum studied to date shows any concomitant changes in the structure of this cortex to add to the putative functional advantage of a large cerebellum [Maseko et al., 2012]. To this end, we used immunohistochemistry for parvalbumin, calbindin and calretinin (EF-hand calcium binding proteins), in conjunction with Nissl and myelin stains, and rapid Golgi impregnations to provide a more detailed description of the structure of the cerebellar cortex of the African elephant. 


\section{Materials and Methods}

Two free-ranging, solitary male African elephants (L. africana; LA1 and LA3, approximate age 20-30 years) scheduled for culling were euthanized as described in Manger et al. [2009]. Permission to sacrifice the animals was granted by the Zimbabwe Parks and Wildlife Management Authority, and ethical permission was obtained from the University of the Witwatersrand Animal Ethics Committee. The animals were treated and used according to the guidelines of this committee, which parallel those set down by the NIH for use of animals in scientific experiments. In situ perfusion-fixation of the brains was conducted by removal of the head, flushing of the cranium with cold saline, and intracarotid perfusion with $4 \%$ paraformaldehyde in $0.1 \mathrm{M}$ phosphate buffer $(\mathrm{PB})$, resulting in relatively short autolysis times (LA1: $160 \mathrm{~min}, \mathrm{LA3}: 110 \mathrm{~min}$ ). The brains were then removed from the skull, placed in the same cold fixative, weighed (LA1: 5,145 g, LA3: 4,835 g) and stored in 4\% paraformaldehyde in $0.1 \mathrm{M}$ PB for $72 \mathrm{~h}$. In order to study the cerebellar cortex of the elephant in more detail, blocks of tissue were excised from the dorsal surfaces of the anterior and posterior portions of the cerebellar hemispheres and the anterior and posterior portions of the vermis of 2 elephants (fig. 2). These tissue blocks were stored in $0.1 \%$ sodium azide in $0.1 \mathrm{M} \mathrm{PB}$ in cold storage for 8 months before staining. Tissue was not taken from the flocculonodular lobe due to the location of this lobe deep within the cerebellum in the roof of the fourth ventricle [Shoshani et al., 2006] and the damage that accessing this region would have caused to the specimens. Tissue blocks were subdivided and processed in different ways to prepare sections appropriate for neuron counting, calculation of neuron density, and also for the structural description of the various neurons located within the different layers of the cerebellar cortex using the Golgi stain.

\section{Golgi Staining}

Blocks of tissue were trimmed to $3-5 \mathrm{~mm}$ in thickness and coded to prevent experimenter bias. These blocks were then processed according to the modified rapid Golgi technique of Scheibel and Scheibel [1978]. Consistent with previous research [Jacobs et al., 1997, 2001, 2011], processed tissue was serially sectioned at $120 \mu \mathrm{m}$ with a vibratome.

\section{Describing and Quantifying Neuronal Morphology from Golgi-Stained Material}

Prior to quantification, all Golgi-stained sections were examined to determine cell types. Golgi-stained neurons were identified according to their differing morphologies and location within the cerebellar cortex. The neurons of interest in the current study included the basket cells, stellate cells, Golgi type II cells and Lugaro cells. Purkinje cells were not traced due to the extent of their dendritic branching and density of dendritic spines, making them too complex to quantify accurately with a Golgi preparation. Granule cells did not stain in the current preparation. Five neurons of each type were chosen and traced to record their morphology in three dimensions. A Neurolucida system (MBF Bioscience, Williston, Vt., USA) coupled to an Olympus BH-2 microscope and using a Planachromat $40 \times($ N.A. 0.70) dry objective was used to quantify the neurons in three dimensions along their $\mathrm{x}-, \mathrm{y}-$ and $\mathrm{z}$-coordinates. First, the soma was traced at its largest point without changing the $\mathrm{z}$-coordinate to give an estimate of its

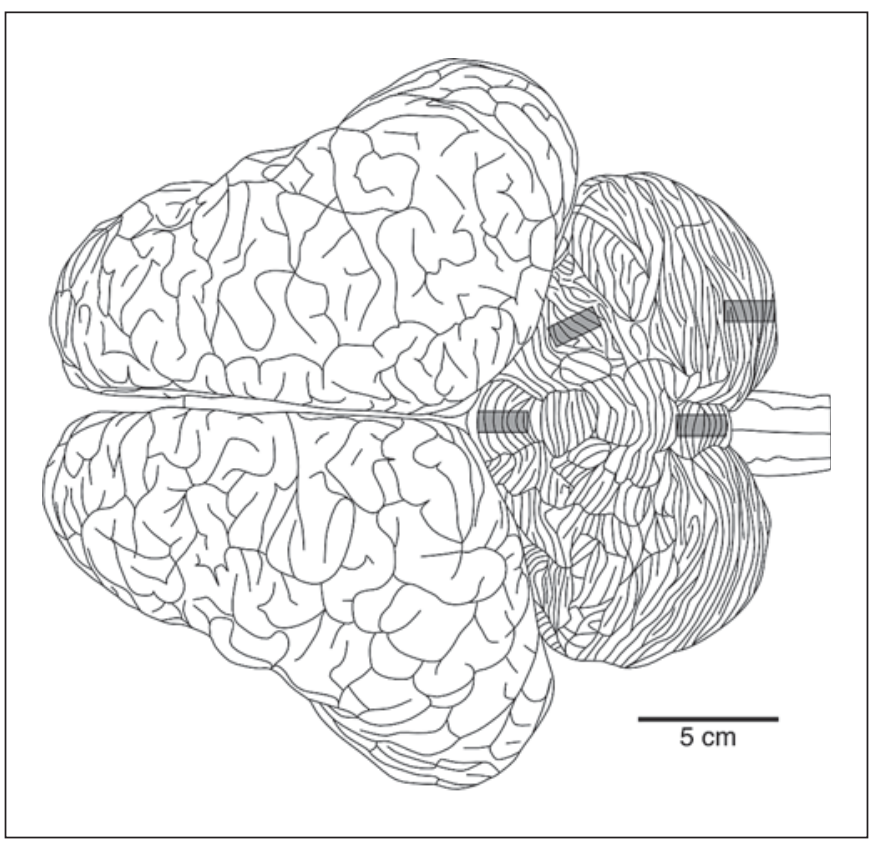

Fig. 2. Drawing of the dorsal view of the African elephant brain showing the approximate location and size of the tissue blocks taken for use in the current study.

cross-sectional area [Jacobs et al., 2001]. The dendrites were then traced from their origin at the soma and followed as they tapered and branched all the way to their termination. Several aspects of the neurons were measured to analyze the sizes and proportions of the different cell types; these include soma size, soma depth from the pial surface, dendritic length and dendritic tortuosity. The diameter of the dendrites was also quantified, along with the number of branches for each dendrite. Broken tips were labeled as incomplete endings. The tortuosity index was calculated by dividing the total length of dendritic segments from the origin point on the cell body to the end point, by the length of a vector from the dendritic origin point on the soma to the dendritic end. A tortuosity index of 1 would indicate a straight line, whereas a tortuosity index greater than 1 indicates that the path of the dendrites is more complex than a straight line [Foster and Peterson, 1986; Wen et al., 2009].

\section{Nissl, Myelin and Immunohistochemical Staining}

A one-in-five series of sections was stained for Nissl substance with cresyl violet, silver staining for myelin and immunohistochemically with antibodies to calbindin, calretinin and parvalbumin from each block of tissue. Sections (50 $\mu \mathrm{m}$ thick) used for the Nissl series were mounted on $0.5 \%$ gelatin-coated glass slides, cleared in a solution of 1:1 chloroform and absolute alcohol, then stained with $1 \%$ cresyl violet. Sections for the myelin series were stored in $5 \%$ formalin at $4{ }^{\circ} \mathrm{C}$ for 2 weeks, mounted on $1 \%$ gelatincoated slides and stained with a modified silver method [Gallyas, 1978]. For immunohistochemical staining, the sections were first treated for $30 \mathrm{~min}$ with an endogenous peroxidase inhibitor (49.2\% methanol: $49.2 \% 0.1 \mathrm{M} \mathrm{PB}: 1.6 \%$ of $30 \% \mathrm{H}_{2} \mathrm{O}_{2}$ ) followed by 
Table 1. Stereological parameters used for counting in the different cerebellar cortical regions in the African elephant

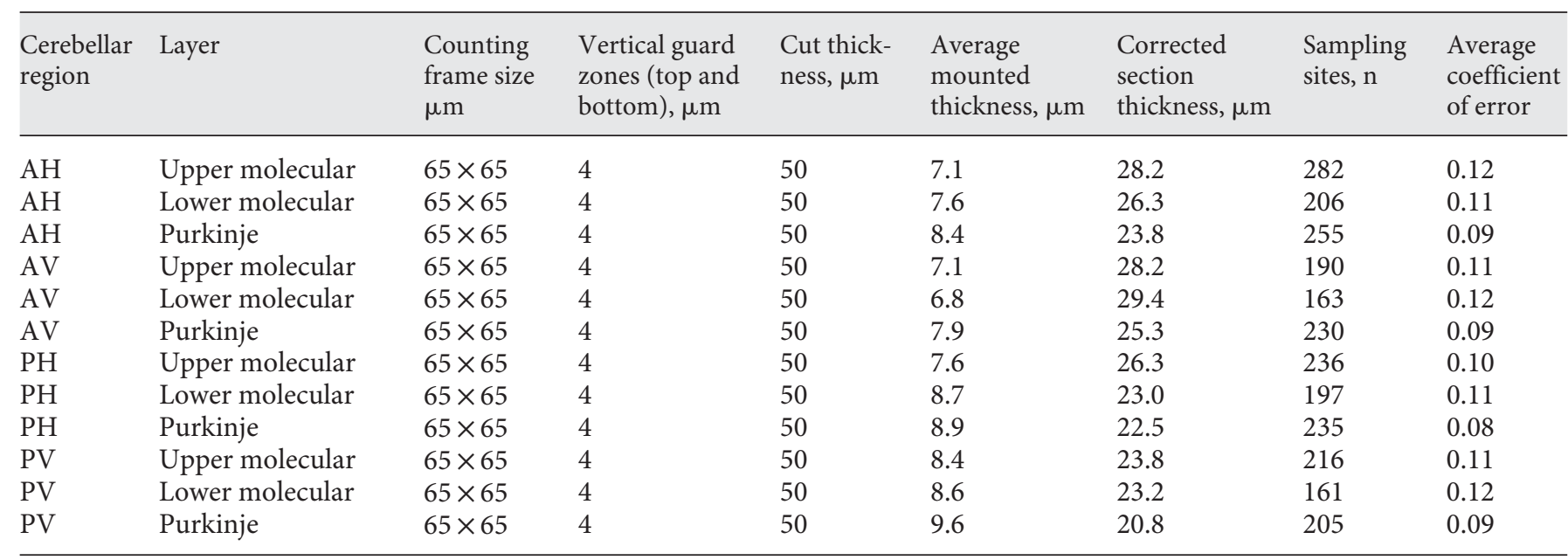

$\mathrm{AH}=$ Anterior cerebellar hemisphere; $\mathrm{AV}=$ anterior cerebellar vermis; $\mathrm{PH}=$ posterior cerebellar hemisphere; $\mathrm{PV}=$ posterior cerebellar vermis.

three 10 -min rinses in $0.1 \mathrm{M}$ PB. This was followed by a 2-hour pre-incubation at room temperature, in a solution (blocking buffer) containing 3\% normal goat serum (Chemicon), $2 \%$ bovine serum albumin (Sigma) and $0.25 \%$ Triton X-100 (Merck) in $0.1 \mathrm{M}$ $\mathrm{PB}$. The sections were then placed in a primary antibody solution containing the appropriately diluted antibody in blocking buffer for $48 \mathrm{~h}$ at $4^{\circ} \mathrm{C}$. To reveal calbindin immunoreactivity $(\mathrm{CB}+)$ we used anti-calbindin antibody (CB-300, SWANT, raised in rabbit) at a dilution of 1:10,000. To reveal calretinin immunoreactivity (CR+), we used anti-calretinin antibody (7699/4, SWANT, raised in rabbit) at a dilution of 1:10,000. To reveal parvalbumin immunoreactivity $(\mathrm{PV}+)$, we used anti-parvalbumin antibody (PV-28, SWANT, raised in rabbit) at a dilution of 1:20,000. This step was followed by three $10-\mathrm{min}$ rinses in $0.1 \mathrm{M} \mathrm{PB}$, after which the sections were incubated in a secondary antibody for $2 \mathrm{~h}$. The secondary antibody solution contained a 1:1,000 dilution of biotinylated anti-rabbit IgG (BA-100 Vector) in blocking buffer containing 3\% normal goat serum and $2 \%$ bovine serum albumin in $0.1 \mathrm{M} \mathrm{PB}$. After three 10 -min rinses in $0.1 \mathrm{M} \mathrm{PB}$, the sections were incubated for $1 \mathrm{~h}$ in $\mathrm{AB}$ solution (Vector Labs) and rinsed again. The sections were then treated in a solution of $0.05 \%$ 3, $3^{\prime}$-diaminobenzidine in $0.1 \mathrm{M}$ PB for $5 \mathrm{~min}$, following which $3 \mu \mathrm{l}$ of $30 \% \mathrm{H}_{2} \mathrm{O}_{2}$ was added to each $1 \mathrm{ml}$ of solution in which each section was immersed. Development was monitored visually under a low-power stereomicroscope and allowed to continue until the background staining was at a level at which it could assist reconstruction without obscuring the immunoreactive structures. To arrest development, sections were placed in $0.1 \mathrm{M} \mathrm{PB}$, and then rinsed twice more in the same solution. Sections were mounted on glass slides coated with $0.5 \%$ gelatin and left to dry overnight. They were then dehydrated in a graded series of alcohols, cleared in xylene and coverslipped with Depex. The observed immunostaining patterns support the specificity of the antibody for the antigens in the African elephant as they are compatible with observations made in other species [Rogers, 1989; Celio, 1990; Résibois and Rogers, 1992; For- tin et al., 1998; Ashwell et al., 2007; Kalinichenko and Pushchin, 2008]. It was not feasible to undertake Western blot control testing in the elephant materials.

\section{Quantification of Neuron Density}

Utilizing a design-based stereologic approach, the density of total neurons from a series of Nissl-stained sections was estimated. For quantification, three sections spaced $400 \mu \mathrm{m}$ apart were used. Within each region of interest, the molecular layer, the Purkinje cell layer and granule cell layer were outlined from two folia in StereoInvestigator software (MBF Bioscience) using a $2.5 \times$ objective. The optical dissector combined with fractionator sampling was used [Mouton, 2002] to obtain estimates of neuronal density following the methods of Sherwood et al. [2007]. Neuronal counts were performed using a $63 \times$ oil-immersion objective when the nucleolus was encountered within the permitted boundaries of the dissector frame. A pilot study determined the optimal sampling parameters and grid dimensions to place dissector frames $(65 \times 65 \times 4 \mu \mathrm{m})$ in a systematic-random manner. Counting frames and sampling grid sizes were optimized to achieve a mean coefficient of error of $10 \%$ or less [Gundersen and Jensen, 1987], while a guard distance of $1 \mu \mathrm{m}$ was used during neuron counting to avoid introduction of errors due to sectioning artifacts [West et al., 1991] (table 1).

The stereologic analyses resulted in sampling an average of 177 counting frames per region for each neuron type, with a total of 5,665 counting frames investigated and a total of 3,860 neurons sampled. We categorized each neuron that fell within the optical dissectors according to its morphological type (i.e. Purkinje, Lugaro, Golgi, stellate, basket or unipolar brush). Following a previous study of the cellular composition of the cerebellar cortex in humans [Whitney et al., 2009], we defined the upper $2 / 3$ of the molecular layer as the location of stellate cells and the lower $1 / 3$ as the region containing basket cells. This was consistent with the distribution of calretinin immunoreactive basket cells that we ob- 
Fig. 3. Low-power photomicrographs of stained sections through the African elephant cerebellar cortex showing the various layers and neuronal elements revealed with the immunohistochemical stains. a Nissl stain. b Parvalbumin immunostaining. c Calbindin immunostaining. d Calretinin immunostaining. Scale bar = $500 \mu \mathrm{m}$ and applies to all.
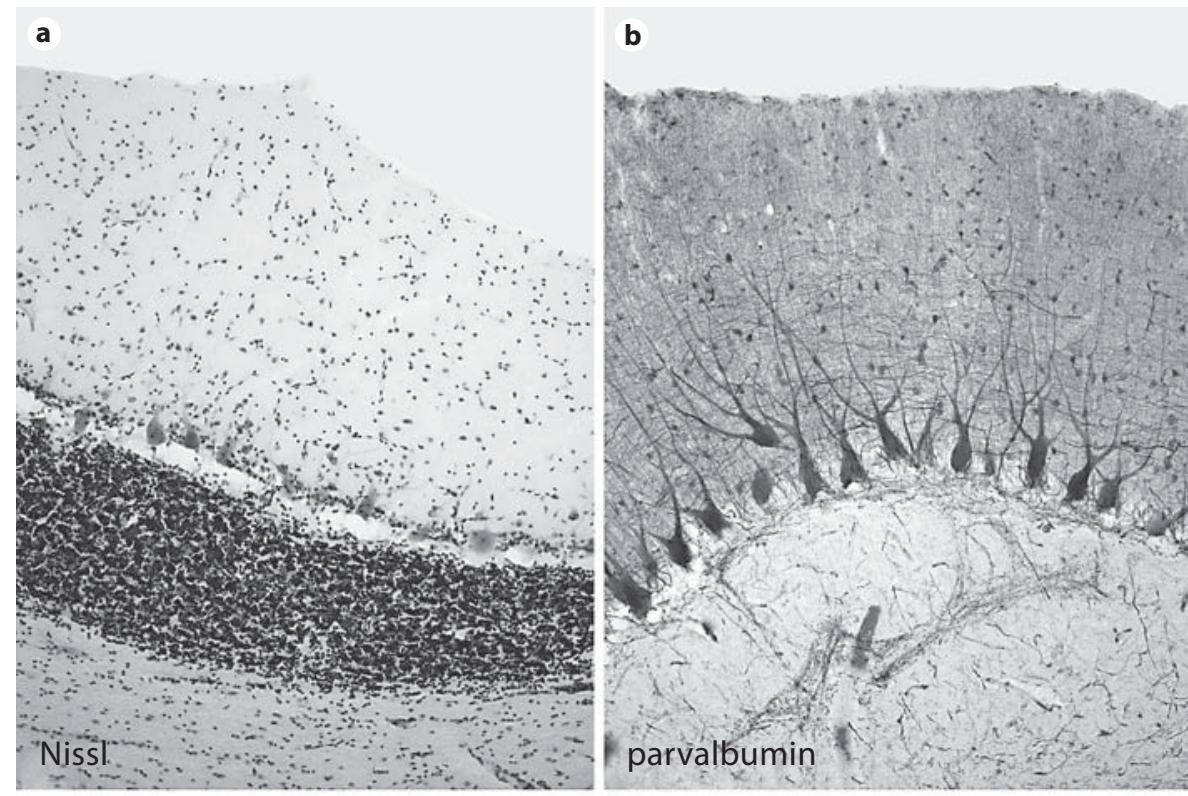

c

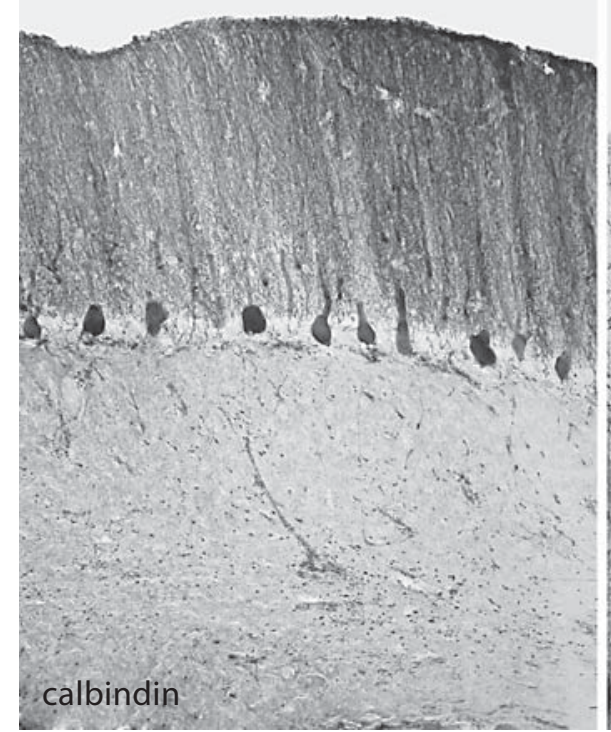

d

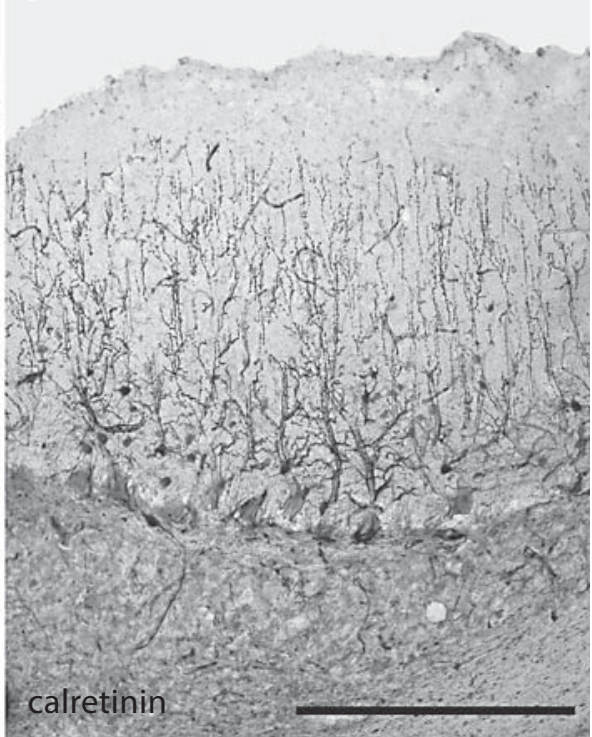

served in the lower portion of the molecular layer in elephant sections. We did not attempt to estimate the density of granule cells. In addition, the volume of the neuron types was estimated using the optical rotator technique, with four sampling rays.

\section{Results}

The African elephant possesses three cell layers as is typical of other mammals and as reported previously for the elephant [for review see Cozzi et al., 2001]. The layers include the outermost molecular layer, in which the in- hibitory interneurons classified as basket cells and stellate cells were located, the Purkinje cell layer with large cell bodies forming a lamina of a single cell's width, underneath which a cell-sparse lamina was observed, and the innermost granule cell layer that contained densely packed granule cells, Golgi type II cells, Lugaro cells and unipolar brush cells (fig. 3).

\section{The Molecular Layer}

This outermost layer contained stellate cells and basket cells (fig. 3-5). The stellate cells, as previously ob- 
Fig. 4. Images demonstrating the morphology of the stellate cells observed in the upper portions of the molecular layer of the African elephant cerebellar cortex. a Neurolucida tracing of a stellate cell. Scale bar $=100 \mu \mathrm{m}$. b Photomicrograph of calbindin-immunostained stellate cell. Scale bar $=100 \mu \mathrm{m}$. c-e Photomicrographs of Golgi-stained stellate cells. Magnification $\times 20(\mathbf{c}, \mathbf{d}), \times 10(\mathbf{e})$. f Photomicrograph of Golgi-stained parallel fibers in the upper portions of the molecular layer. Magnification $\times 40$.
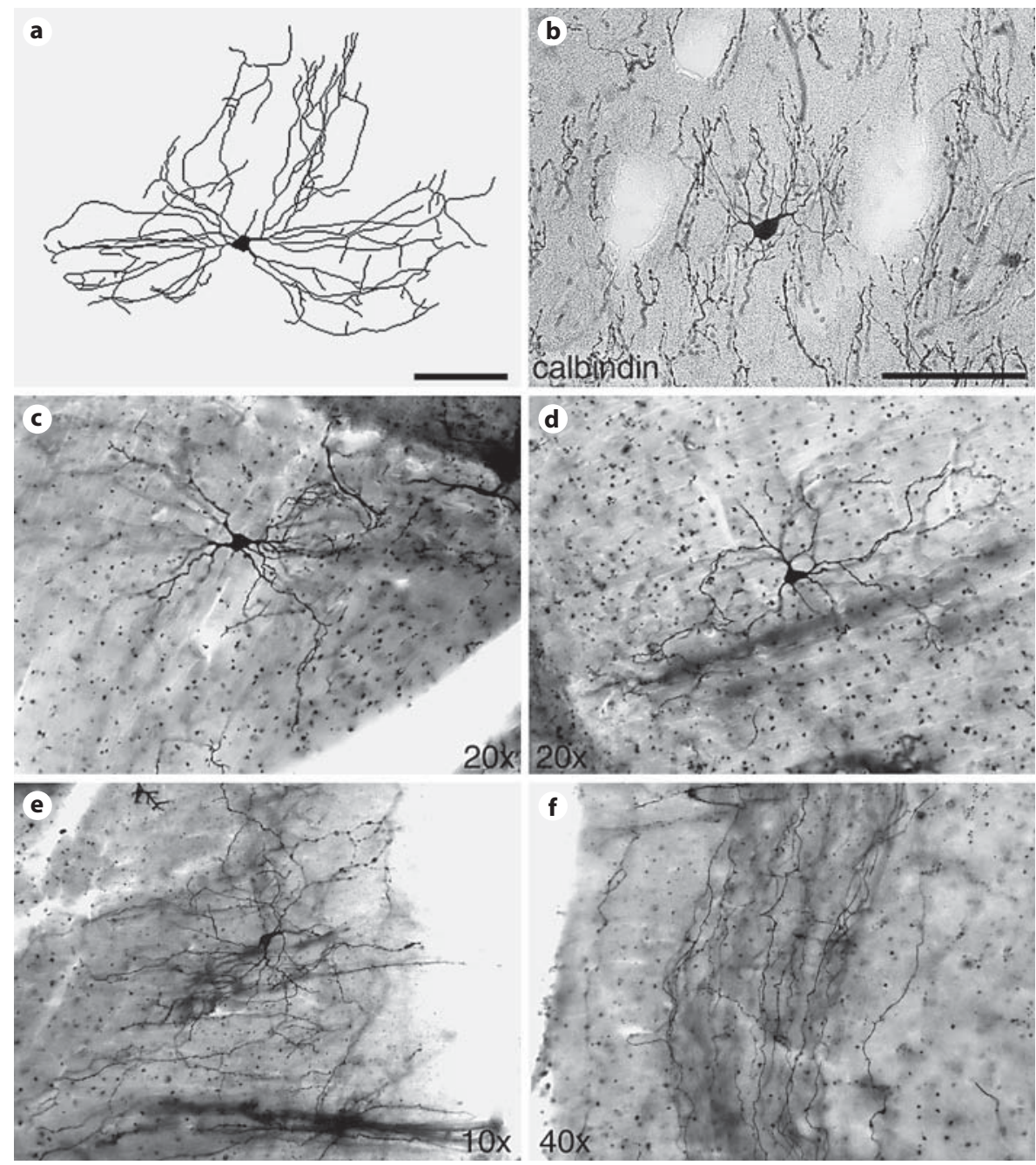

served to be typical for mammalian cerebellar cortices [Whitney et al., 2009], were in the upper two-thirds of the molecular layer, while the basket cells were found in the lower third of the molecular layer. Horizontally oriented $\mathrm{PV}+$ fibers were abundant in the lower half of the molecular layer, in the region of the secondary and tertiary branches of the Purkinje cells, and less abundant in the upper half of this layer (fig. 3). These fibers most likely represent the parallel fibers that emerge from granule cells. $\mathrm{CB}+$ boutons were observed through the full depth of the molecular layer and appeared to be lying adjacent to the dendritic spines of the Purkinje cells (fig. 6). CR+ axons and boutons, which we presume to be the climbing fibers, were observed to outline the extensive dendritic arborizations of the Purkinje cells through to the upper parts of the molecular layer along the entire extent of the Purkinje cell dendrites (fig. 3).

\section{Stellate Cells}

Similar to other mammals, the somata of the stellate cells in elephants resemble the shape of a star (fig. 4). From the soma, several long, tortuous, extensively branching dendrites radiate to provide the soma with its particular shape (fig. 4). The primary dendrites appear to extend in all directions. The dendrites were observed to bifurcate between two and five times along their length, and while no clear dendritic spines were evident, small varicosities in the dendrites may represent regions where synaptic contacts are made. The stellate cells were observed to be $\mathrm{PV}+$ and $\mathrm{CB}+$ throughout the cytoplasm of the soma and in the thicker parts of the primary and secondary dendritic branches. Our quantitative analysis of the Golgistained materials revealed that the stellate cells had an average soma profile area of $183.49 \mu \mathrm{m}^{2}$ (the smallest of the cells analyzed using the Golgi stain), an average total den- 
Table 2. Average soma areas, total dendritic lengths and dendritic tortuosity based on the analysis of the Golgi-stained materials in the African elephant cerebellar cortex

\begin{tabular}{lcccc}
\hline Neuron type & $\mathrm{n}$ & $\begin{array}{l}\text { Average soma area } \\
\mu \mathrm{m}^{2} \pm \mathrm{SD}\end{array}$ & $\begin{array}{l}\text { Average total dendritic } \\
\text { length, } \mu \mathrm{m} \pm \mathrm{SD}\end{array}$ & $\begin{array}{l}\text { Average dendritic } \\
\text { tortuosity } \pm \text { SD }\end{array}$ \\
\hline Stellate & 5 & $183.49 \pm 47.61$ & $5,515.40 \pm 1,562.77$ & $1.18 \pm 0.03$ \\
Basket & 5 & $444.55 \pm 189.07$ & $6,345.78 \pm 2,415.67$ & $1.16 \pm 0.05$ \\
Golgi & 5 & $736.31 \pm 132.01$ & $5,664.20 \pm 878.91$ & $1.19 \pm 0.02$ \\
Lugaro & 5 & $1,353.57 \pm 394.78$ & $3,019.14 \pm 883.97$ & $1.12 \pm 0.05$ \\
\hline
\end{tabular}

Table 3. Cell densities and soma volumes in the four regions examined stereologically for Nissl-stained materials in the African elephant cerebellar cortex

\begin{tabular}{|c|c|c|c|c|c|c|c|c|}
\hline \multirow[t]{2}{*}{ Region } & \multicolumn{4}{|c|}{ Average cellular number $/ \mathrm{mm}^{3} \pm \mathrm{SD}$} & \multicolumn{4}{|c|}{ Average somal volume, $\mu \mathrm{m}^{3} \pm \mathrm{SD}$} \\
\hline & $\mathrm{AH}$ & $\mathrm{AV}$ & $\mathrm{PH}$ & PV & $\mathrm{AH}$ & AV & $\mathrm{PH}$ & PV \\
\hline Stellate & $4,529 \pm 1,290$ & $4,245 \pm 50$ & $6,326 \pm 1,126$ & $6,857 \pm 0.76$ & $356 \pm 151$ & $370 \pm 111$ & $450 \pm 114$ & $426 \pm 141$ \\
\hline Basket & $4,672 \pm 108$ & $4,048 \pm 150$ & $5,383 \pm 2,244$ & $5,310 \pm 1,672$ & $735 \pm 266$ & $737 \pm 112$ & $764 \pm 111$ & $718 \pm 168$ \\
\hline Purkinje & $6,276 \pm 3,270$ & $5,894 \pm 585$ & $8,336 \pm 3,110$ & $8,812 \pm 2,961$ & $8,186 \pm 2,744$ & $8,903 \pm 150$ & $8,631 \pm 57$ & $8,311 \pm 1,728$ \\
\hline Unipolar brush & $1 \pm 0.84$ & $1 \pm 0.42$ & $2 \pm 1.17$ & $2 \pm 1.13$ & - & - & - & 2,238 \\
\hline
\end{tabular}

$\mathrm{AH}=$ Anterior cerebellar hemisphere; $\mathrm{AV}=$ anterior cerebellar vermis; $\mathrm{PH}=$ posterior cerebellar hemisphere; $\mathrm{PV}=$ posterior cerebellar vermis.

dritic length of 5,515.40 $\mu \mathrm{m}$ and a tortuosity index of 1.18 (table 2). Stereological analysis of the Nissl-stained material revealed that the average somal volume of the stellate cells ranged between 356 and $450 \mu \mathrm{m}^{3}$ in the different regions examined, and showed that the stellate cell somata from the posterior hemisphere and vermis were significantly larger than the somata observed in the blocks of tissue from the anterior hemisphere and vermis (MannWhitney $U$ test, $\mathrm{p}_{\text {same }}=0.0004$; table 3 ). The posterior hemisphere and vermis also had higher stellate cell densities (up to 6,857 cells $/ \mathrm{mm}^{3}$ ) than the anterior hemisphere and vermis (as low as 4,245 cells $/ \mathrm{mm}^{3}$; table 3). Despite this marked trend towards greater cell densities in the posterior regions of the cerebellum, non-parametric significance testing was unable to detect significant differences in stellate cell densities, likely a result of the small sample sizes (Mann-Whitney $\mathrm{U}$ test, $\mathrm{z}_{3}=-1.59$, $\mathrm{p}_{\text {same }}=0.25$ ).

\section{Basket Cells}

Basket cells were located within the lower third of the molecular layer, with the soma and primary and second- ary dendritic branches being $\mathrm{PV}+$ and $\mathrm{CB}+$, but were less intensely stained than the stellate cells (fig. 3, 5). Some of these neurons were located between the superficial aspects of the Purkinje cell bodies and primary dendrites that intrude into the molecular layer. The somata of the basket cells had a somewhat foreshortened fusiform shape with the longest plane of the cell oriented in a horizontal direction. Three to four primary dendrites were observed to emerge from the horizontal edges of the cell body and extended in the horizontal plane, branching between two and three times (fig. 5). From these primary dendrites, several secondary dendritic branches ramified and extended superficially through the entire molecular layer to the surface of the cerebellar cortex. Clear dendritic spines were not observed on the basket cells; however, as with the stellate cells, small varicosities were observed, potentially representing regions where synaptic contacts could be made (fig. 5).

Quantitative analysis of the Golgi-stained materials showed that the average somal profile area of the basket cells $\left(444.55 \mu \mathrm{m}^{2}\right)$ was over twice as large as the stellate 
Fig. 5. Images demonstrating the morphology of the basket cells observed in the lower portions of the molecular layer of the African elephant cerebellar cortex. a Photomicrograph of calbindin-immunostained basket cell. Scale bar $=100 \mu \mathrm{m}$. b Neurolucida tracing of a basket cell. Scale bar $=100 \mu \mathrm{m}$. c-f Photomicrographs of Golgi-stained basket cells. Magnification $\times 20(\mathbf{c}), \times 10(\mathbf{d}-\mathbf{f})$.
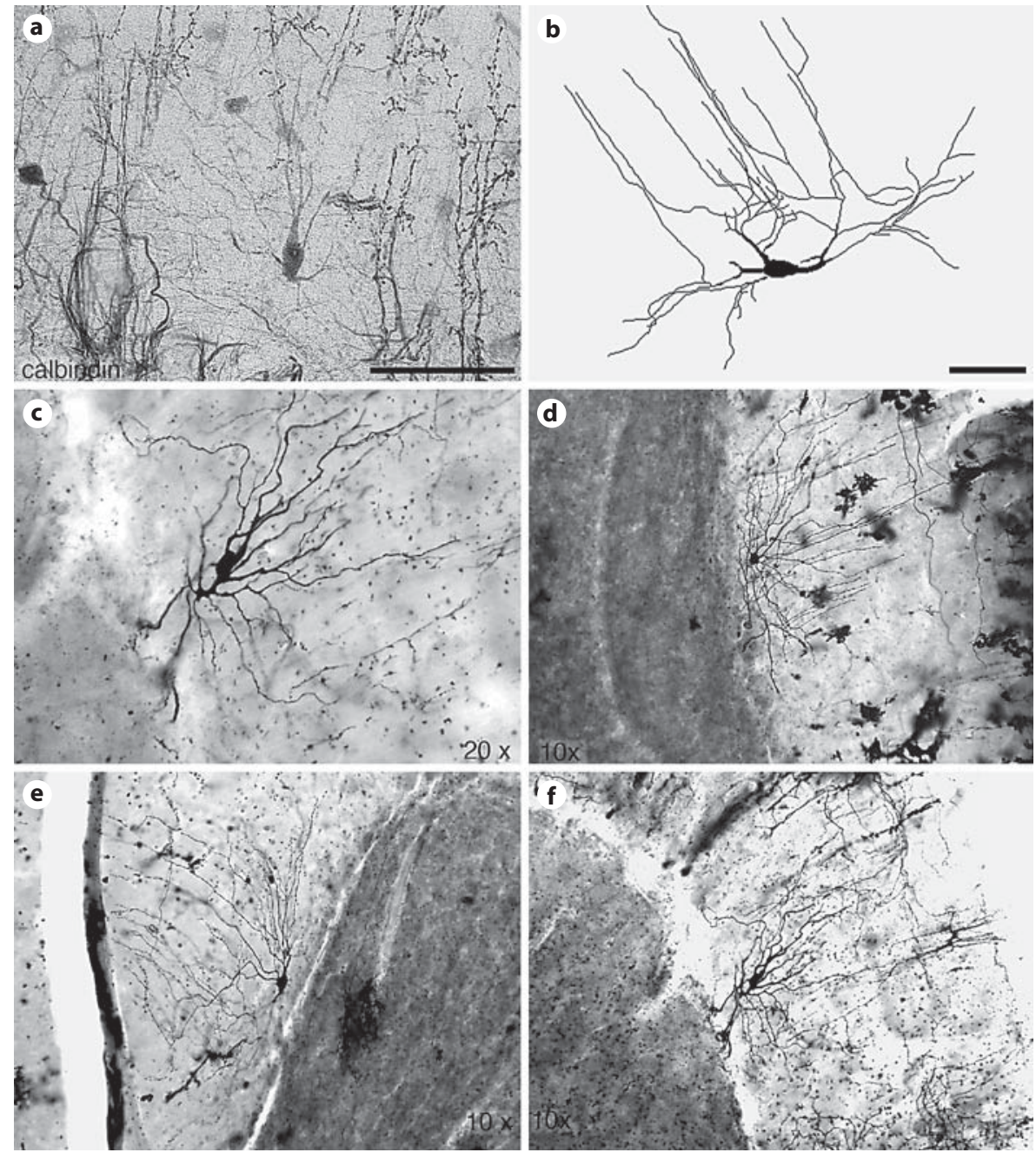

cell (table 2). This two-fold difference in size was confirmed in the stereologic analysis of cell volume, where basket cells had average volumes ranging between 718 and $764 \mu \mathrm{m}^{3}$ in the various blocks of tissue examined (table 3); however, unlike stellate cells, there was no clear difference in average cell volumes in the different regions of the cerebellar cortex studied (Mann-Whitney U test, $\left.\mathrm{p}_{\text {same }}=0.3257\right)$. This distinct size difference allowed the laminar differentiation of the basket cells from the stellate cells. The Golgi-stained basket cells had an average total dendritic length of $6,345.78 \mu \mathrm{m}$ and an average dendritic tortuosity of 1.16 , having a greater dendritic length but less branching and bending than the stellate cells studied (table 2). Stereologic analysis revealed an average cell density ranging from 4,048 to 5,383 cells $/ \mathrm{mm}^{2}$ depending on the region and, as seen for the stellate cells, the density of basket cells in the posterior hemisphere and vermis were higher than in the anterior hemisphere and vermis (table 3); however, we were unable to detect any significant differences in basket cell densities between the anterior and posterior regions of the cerebellum, a result which would likely approach significance with greater sample sizes (Mann-Whitney $\mathrm{U}$ test, $\mathrm{z}_{3}=-1.16$, $\left.\mathrm{p}_{\text {same }}=0.25\right)$.

\section{The Purkinje Cell Layer}

The Purkinje cell layer consisted of one layer of Purkinje cells that were arranged adjacent to each other (fig. 3, 6). In the spaces between the large cell bodies of the Purkinje cells, we noted intense parvalbumin immunoreactivity of what appear to be axons outlining the Purkinje cell body (fig. 6). These PV+ axons were seen to pass around the Purkinje cell bodies and appeared to form the typical T-shaped branches of the parallel fibers 
Fig. 6. Photomicrographs demonstrating the morphology of the Purkinje cells observed in the African elephant cerebellar cortex. a Golgi-stained Purkinje cell. Magnification $\times 4$. b Purkinje cells weakly immunoreactive for parvalbumin. Note the intensely stained axons of the parallel fibers passing around the Purkinje cell somata. c Golgi-stained Purkinje cell. Magnification $\times 10$. d Purkinje cells weakly immunoreactive for calbindin. Scale bar = $100 \mu \mathrm{m}$ (b, d). e Golgi-stained Purkinje cell dendritic arbors. Magnification $\times 4$. f Axon terminals of climbing fibers strongly immunoreactive for calbindin outlining the dendritic arbors of the Purkinje cells in the molecular layer. Scale bar $=50 \mu \mathrm{m}$.
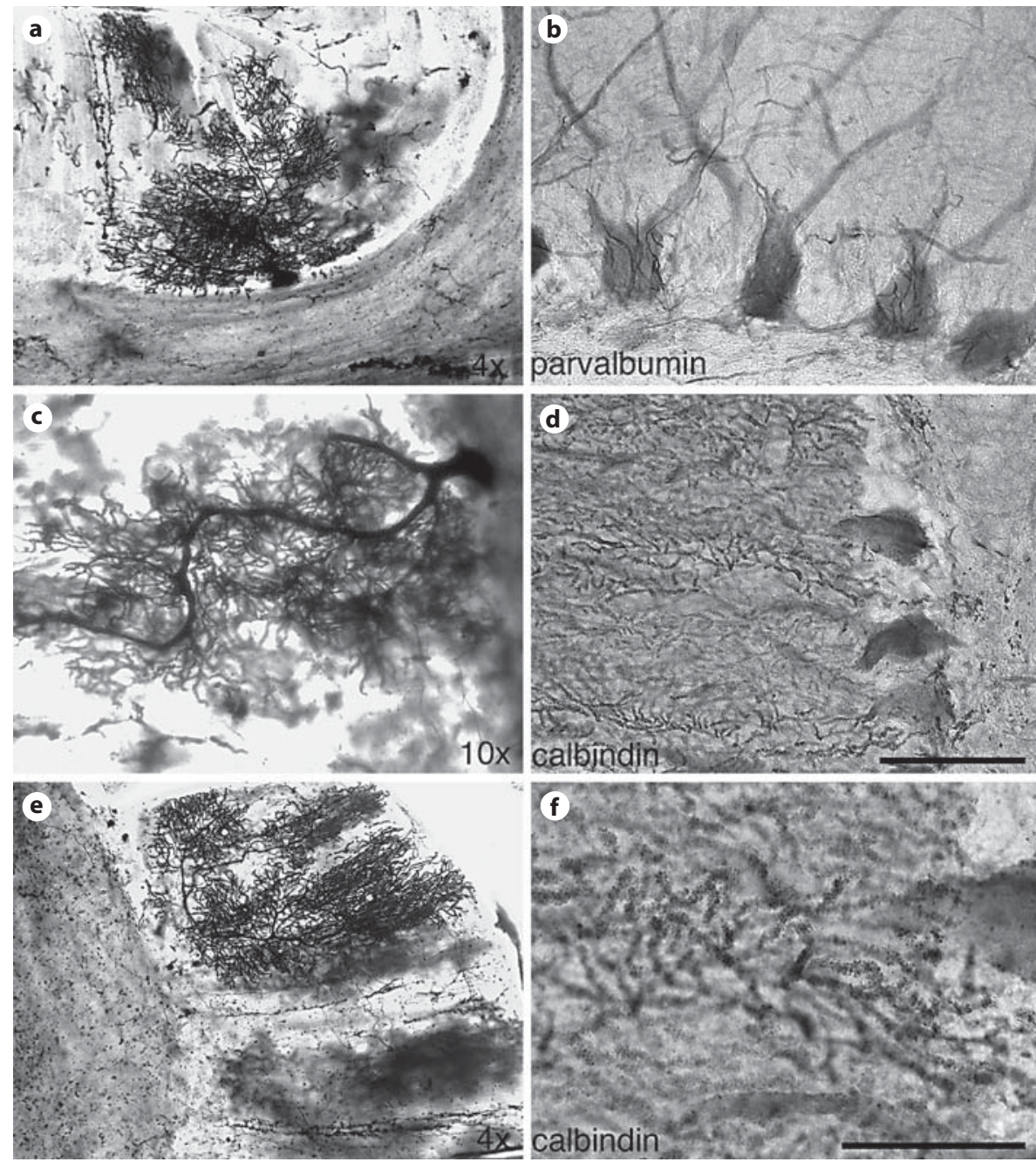

arising from the granule cells in the molecular layer of the cerebellar cortex. CR+ axons, the climbing fibers, were also seen to outline the somata of the Purkinje cells (fig. 6). Beneath the monolayer of the Purkinje cells, a distinct cell sparse region was observed, separating the Purkinje cells from the granule cells. Within this cell-sparse lamina, many horizontally oriented PV+ axons were present, as well as distinct bundles of $\mathrm{CB}+$ axons (fig. 3).

\section{Purkinje Cells}

The somata of the Purkinje cells exhibited the typical piriform shape with extensive fan-shaped branching of the dendrites in the molecular layer (fig. 6). Stereologic analysis revealed that the volume of the somata of the Purkinje cells averaged between 8,186 and $8,903 \mu \mathrm{m}^{3}$ across the regions (table 3), with no significant regional differences (Mann-Whitney U test, $\mathrm{p}_{\text {same }}=0.7256$ ). From the Nissl-stained material we determined that the density of Purkinje cells varied between 5,894 and 8,812 cells/ $\mathrm{mm}^{3}$, with the posterior hemispheric and vermal blocks having higher densities than the anterior hemispheric and vermal blocks (table 3); however, we were unable to detect any significant differences in Purkinje cell densities (Mann-Whitney U test, $\mathrm{z}_{3}=-1.16, \mathrm{p}_{\text {same }}=0.25$ ). The dendrites of the Purkinje cells were highly spinous and had the appearance of very dense bushes projecting into the molecular layer. The Purkinje cells were weakly immunoreactive for both anti-parvalbumin and anti-calbindin antibodies, with the anti-parvalbumin antibody staining the cytoplasm of the soma and the primary dendrites, while the anti-calbindin antibody only stained the cytoplasm of the soma (fig. 6). Interestingly, calbindin immunoreactivity was observed as small boutons surrounding the dendritic arbors of the Purkinje cells in the 
Fig. 7. Images demonstrating the morphology of the Golgi cells observed in the granule cell layer of the African elephant cerebellar cortex. a Photomicrograph of weakly calretinin-immunostained Golgi cell. Scale bar $=100 \mu \mathrm{m}$. b Neurolucida tracing of a Golgi cell. Scale bar $=100 \mu \mathrm{m}$. c, d Photomicrographs of Golgi-stained Golgi cells. Magnification $\times 10$ (c), $\times 20$ (d).
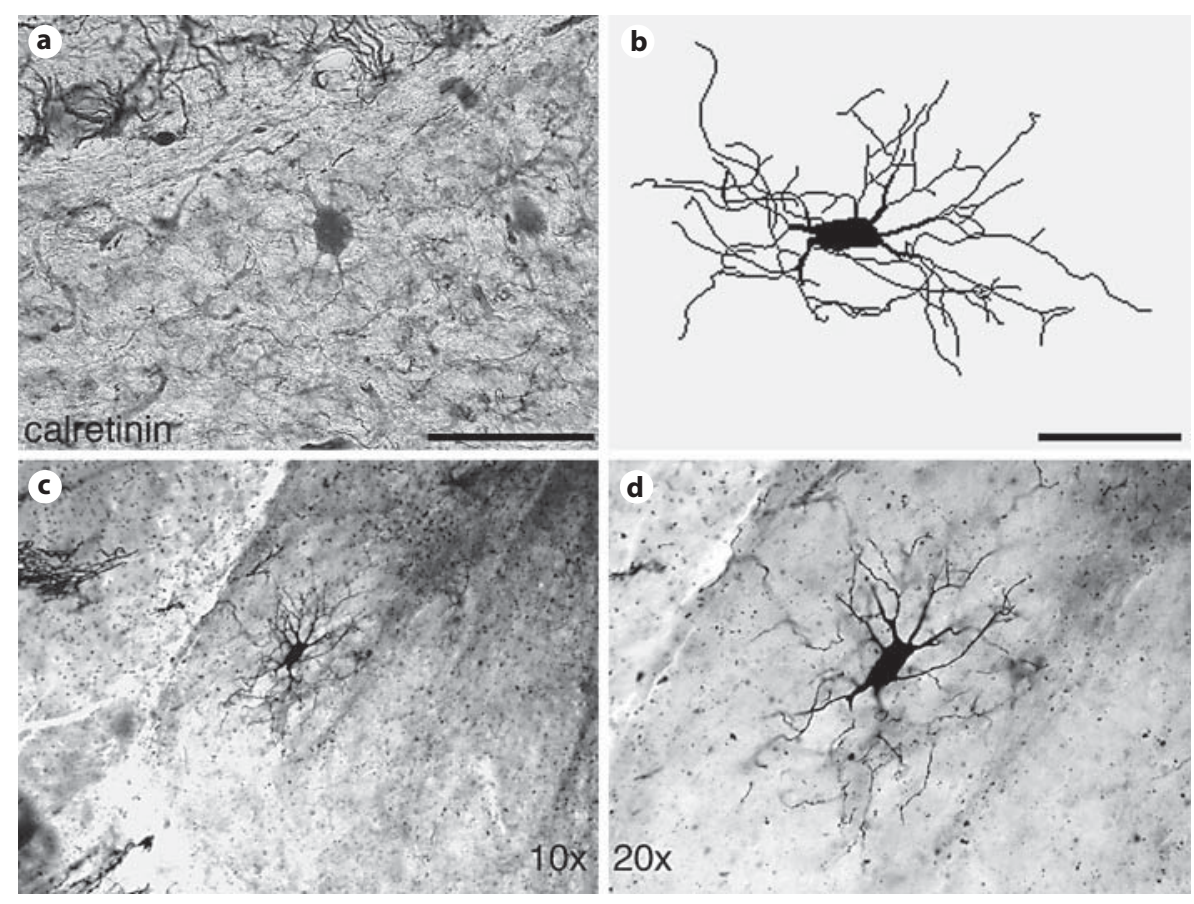

molecular layer. These boutons, presumably axonal terminals of climbing fibers, appear to have an almost one to one correspondence with the dendritic spines of the Purkinje cells and form clear outlines of the Purkinje cell dendrites (fig. 6).

\section{The Granule Cell Layer}

The granule cell layer formed the innermost layer of the cerebellar cortex and was observed to contain four cell types: the granule cells, Lugaro cells, Golgi type II cells and unipolar brush cells (fig. 3). This layer was the most cell-dense of the cortical layers, mainly due to the granule cells which, although relatively small in soma volume, are the most numerous of the cells and account for approximately half the cells in the entire mammalian central nervous system [Ito, 2006]. Thin PV+ axons were observed traversing the granule cell layer, presumably arising from the granule cells and extending into the Purkinje cell layer, or descending from the Purkinje cells on their path to the deep cerebellar nuclei (fig. 3). $\mathrm{CB}+$ axons were also observed to cross through the granule cell layer and these are also likely to be descending axons arising from the Purkinje cells (fig. 3).

Granule Cells

Granule cells were very numerous, exhibited a high density and had relatively small soma sizes, which ap- peared spherical in shape (fig. 3). No granule cells were stained with the Golgi technique and, while the parallel fibers that presumably emerge from these cells were observed to be PV+ (fig. 3,4$)$, the somata of the granule cells did not evince any immunoreactivity for parvalbumin, calbindin or calretinin. We did not undertake any stereologic assessment of the size or density of the granule cells; however, a previous report [Lange, 1975] indicated that there were approximately 807 granule cells per 0.001 $\mathrm{mm}^{3}$, or to make the comparison to the values determined for other cells in the current study, there would be approximately 807,000 granule cells per $\mathrm{mm}^{3}$ in the elephant cerebellar cortex - more than 2 orders of magnitude greater than that observed for the other neurons for which cell density was estimated.

\section{Golgi Type II Cells}

Golgi type II cells were observed within the upper half of the granule cell layer and were weakly immunoreactive for calbindin. They were readily distinguishable from other neurons in the same layer on the basis of having a much larger soma size than the surrounding granule cells and much smaller soma than the Lugaro neurons (fig. 3, 7). The somata of the Golgi type II cells were observed to be elongated and spherical in shape and Golgi-stained material indicated that they had an average soma profile area of $736.31 \mu \mathrm{m}^{2}$ (table 2), while our stereologic inves- 
Fig. 8. Images demonstrating the morphology of the Lugaro cells observed in the granule cell layer of the African elephant cerebellar cortex. a Neurolucida tracing of a Lugaro cell. Scale bar $=100$ $\mu \mathrm{m}$. b, c Photomicrographs of calretinin immunostained Lugaro cells. Scale bar in $\mathbf{c}=100 \mu \mathrm{m}$ and applies to $\mathbf{b}$ and $\mathbf{c}$. d, e Photomicrographs of Golgi-stained Lugaro cells. Magnification $\times 10(\mathbf{d}, \mathbf{e})$.
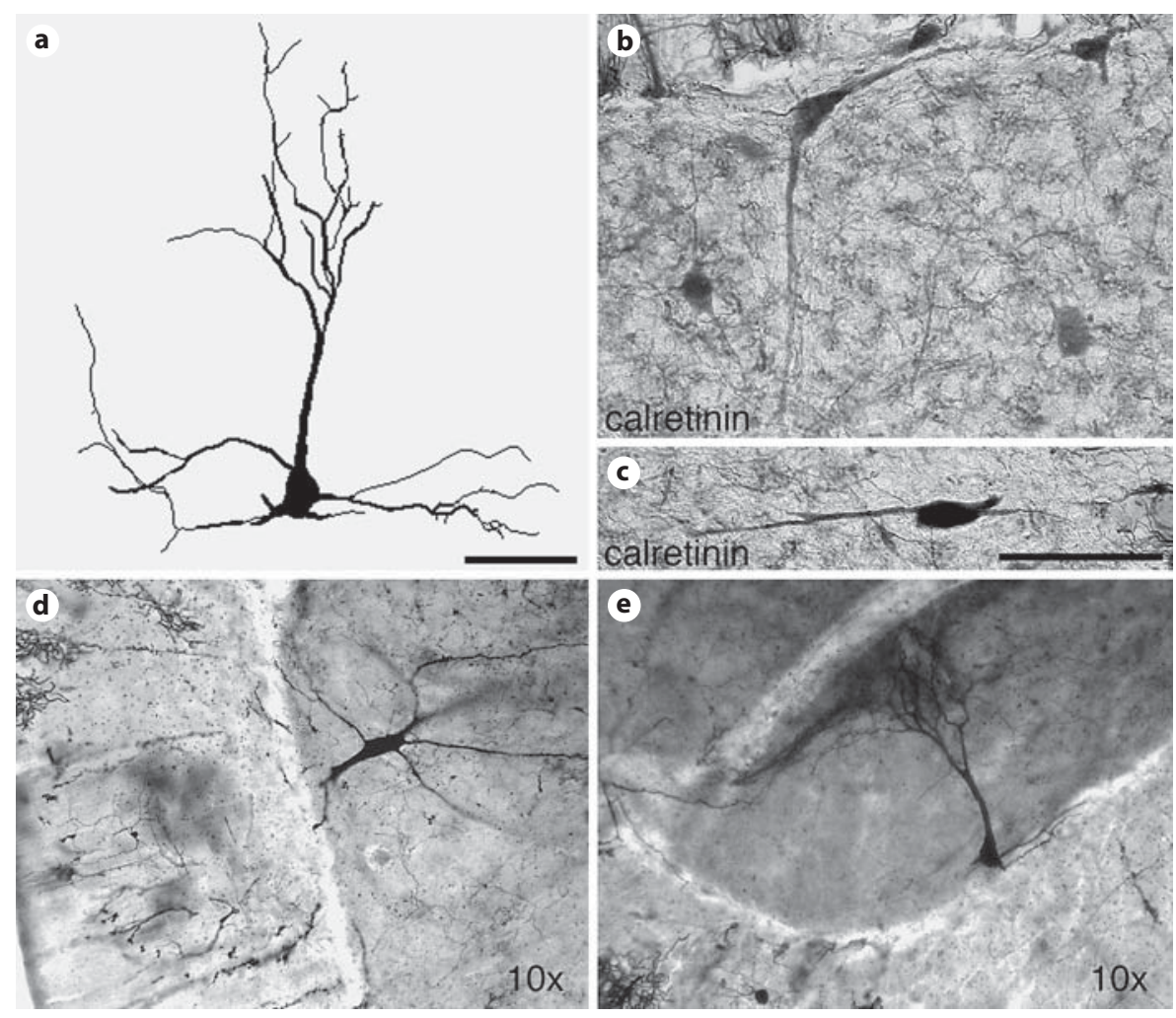

tigation indicate average soma volumes of between 1,816 and $2,939 \mu^{3}$ in the various regions investigated (table 3). Between 4 and 7 thick dendrites were observed to emerge from the elongated edges of the soma, but the thickness of these dendrites tapered rapidly within 50 $\mu \mathrm{m}$ of the soma and became relatively thin (fig. 7). The dendrites branched extensively and, while the full dendritic field showed a slight trend towards a preferred orientation in the horizontal plane, this was not marked. Our analysis of the Golgi-stained material provided an average dendritic length of 5,664.2 $\mu \mathrm{m}$ and an average dendritic tortuosity of 1.19 (table 2). The Golgi type II cells thus had the most complex arrangement of dendritic arbors among all the cells analyzed with the Golgi method in the current study. Our stereologic analysis of the Golgi type II cells indicated that they were not very numerous compared to the other cell types and had densities ranging between 44 and 54 cells $/ \mathrm{mm}^{3}$ and no significant variation among cerebellar cortical regions (table 3; Mann-Whitney U test, $\mathrm{z}_{3}=0.39$, $\mathrm{p}_{\text {same }}=0.70$ )

\section{Lugaro Cells}

The somata of the Lugaro cells were consistently located within the superficial most parts of the granule cell layer, subjacent to the cell sparse zone of the Purkinje cell layer (fig. 3, 8). The most striking feature of these neurons was the very large size of the soma, which evinced a triangular or fusiform shape in cross-section, the size and shape of which was exaggerated by the two to three very large dendrites that emerged from the cell body (fig. 8). The two different soma shapes have been considered to represent two different types of Lugaro neurons [MelikMusyan and Fanardzhyan, 2004] and, in the current study, we observed that the triangular-shaped somata were found immediately deep to the Purkinje cell layer, whereas the fusiform-shaped somata were located approximately $100 \mu \mathrm{m}$ into the granule cell layer. In Golgistained tissue, these neurons were found to have average somal profile areas of $1,353.57 \mu \mathrm{m}^{2}$ (table 2), with the stereologic analysis determining average cell volumes ranging between 15,530 and $18,629 \mu^{3}$ (table 3). Thus, the Lugaro neurons were by far the largest neurons observed in the elephant cerebellar cortex (tables 2, 3). Two to three large dendrites were observed to emerge from the somata of the Lugaro neurons, with one exceptionally large dendrite extending deep through the granule cell layer forming a moderately branched dendritic plexus in the lower half of the granule cell layer. The smaller dendrites ap- 
peared to be more horizontally oriented, arborizing mostly within the cell-sparse sublayer of the Purkinje cell layer. Golgi-stained material revealed an average dendritic leng th of 3,019.14 $\mu \mathrm{m}$ and an average dendritic tortuosity of 1.12 (table 2); thus, although the somata of these neurons were large, the extent of the dendritic arborization and its complexity were among the lowest of those analyzed in the current study. It should be noted here that these dendritic measures probably greatly underestimate the extent of the Lugaro dendritic system; due to the fact that these cells were so large, it is likely that the complete dendritic system was not contained within the $120-\mu \mathrm{m}$ thick sections [see Jacobs et al., 1997]. The soma and primary dendrites of the Lugaro neurons were immunoreactive for the calretinin antibody (fig. 8). Stereologic analysis of the Nissl-stained materials revealed that the density of these neurons was not high, ranging between 17 and 26 neurons $/ \mathrm{mm}^{3}$ in the different regions of the elephant cerebellar cortex and showed no significant regional variation (table 3; Mann-Whitney $\mathrm{U}$ test, $\mathrm{z}_{3}=-0.39$, $\mathrm{p}_{\text {same }}=$ 0.70).

\section{Unipolar Brush Cells}

Only a small number of unipolar brush cells were observed in the current study, and they evinced the morphology typical of these neurons as described in other mammals, having small, oval somata (average soma volume of 2,238 $\mathrm{mm}^{2}$; table 3), with a single short dendrite leading to a small dendritic arbor. The stereologic investigation revealed an average density of unipolar brush neurons of between 1 and 2 neurons $/ \mathrm{mm}^{3}$ (table 3). No unipolar brush cells were stained in the Golgi materials and we failed to observe any of these neurons with immunohistochemistry for the calcium-binding proteins.

\section{Discussion}

The current study contributes substantial qualitative and quantitative information to previous observations on the histological appearance of the cerebellar cortex of elephants [reviewed in Cozzi et al., 2001]. As elephants have the largest relative cerebellar size of all mammals studied to date [Maseko et al., 2012], it was of interest to determine whether any associated changes in the microstructure of the cerebellar cortex were apparent. In addition, elephants have one of the largest cerebella in absolute terms among mammals (averaging $924 \mathrm{ml}$ ). If one were to extrapolate from known cetacean cerebellar allometry [Maseko et al., 2012], the volume of the elephant cerebel- lum is only exceeded by the predicted cerebellar volumes of the sperm whale, Physeter macrocephalus (brain mass $=7,818 \mathrm{~g}$, predicted cerebellar volume $=1,140$ $\mathrm{ml}$ ), the fin whale, Balaenoptera physalis (brain mass = $7,111.43 \mathrm{~g}$, predicted cerebellar volume $=1,037 \mathrm{ml}$ ) and the humpback whale, Megaptera novaeangliae (brain mass $=6,439 \mathrm{~g}$, predicted cerebellar volume $=938 \mathrm{ml}$ ) [brain mass data from Manger, 2006].

We found that the elephant cerebellar cortex exhibited a range of features that are typical among mammals in terms of both the laminar and cellular organization. The three-layered cerebellar cortex observed in the elephant is common to all mammals, and indeed the vast majority of vertebrates [Palay and Chan-Palay, 1974]. Moreover, the neuronal types and their general morphology (stellate cells, basket cells, Purkinje cells, granule cells, Golgi type II cells, Lugaro neurons and unipolar brush neurons) are also typical, with no novel neuronal types being observed in the African elephant, although we did not identify any neurons that could be considered candelabrum neurons [Lainé and Axelrad, 1994]. The apparent circuitry (parallel fibers, climbing fibers and mossy fibers) and neurochemistry of some aspects of the cell types and circuitry also reveal a phenotype that did not show any major departure compared to previous observations in other mammals.

Certain differences from other species were noted, and these are of interest to discuss in more detail. These include such features as the size and morphology of the individual neurons examined under Golgi staining, especially the Lugaro neurons, the overall densities of the neurons in the cerebellar cortex and the variance related to the patterns of staining for the calcium-binding proteins examined. These are detailed here, compared with data obtained across other mammalian species, and then contextualized in terms of the functional aspects of the relative and absolute size of the elephant cerebellum.

\section{Neuronal Morphology as Revealed with Golgi Impregnations and Immunostaining}

As mentioned above, the general morphology of the neurons stained with both the Golgi and immunohistochemical methods revealed that for the most part, the identity of neurons could be readily assessed and the neurons assigned to a particular type as described previously for the mammalian cerebellar cortex. Notably, the Lugaro neurons of elephants have a particularly large size, with an average volume of approximately $17,000 \mu \mathrm{m}^{3}$ (table 3). This specific enlargement in size of the Lugaro neurons, as compared to other neurons within the cere- 
bellar cortex, especially the functionally similar Golgi type II neurons, has not been reported in other mammalian species studied, including laboratory rat [Rogers, 1989; Celio, 1990; Résibois and Rogers, 1992], squirrel monkey [Fortin et al., 1998], cat [Melik-Musyan and Fanardzhyan, 2004], echidna [Ashwell et al., 2007], and bottlenose dolphin and harbor porpoise [Kalinichenko and Pushchin, 2008]. Melik-Musyan and Fanardzhyan [2004] propose that the Lugaro neurons should be considered as a distinct neuronal type, rather than being grouped with the Golgi type II neurons, and the current observations in the African elephant support this notion due to the specific enlargement of the Lugaro neurons. While the exact function of the Lugaro neurons in cerebellar cortical circuitry remains elusive, it appears that they play an important role in the mechanism of long-term depression of neuronal activity [Melik-Musyan and Fanardzhyan, 2004].

Although the cerebellum has been widely studied, particularly in terms of gross anatomy, neuronal types and their connectivity, little is known regarding the quantitative and qualitative aspects of neuronal variation across species. The analysis of the Golgi-stained material in the current study has provided quantitative information related to specific neuronal morphologies in one of the largest cerebella of all mammals. Unfortunately, similar comparative data have not yet been published, but our unpublished observations on a range of different mammalian species [e.g. Wahl et al., 2012] suggests that scaling occurs, in terms of neuronal size and dendritic complexity, with larger cerebella having larger neurons and greater dendritic complexity. Lange [1975] has already indicated that for certain cell types in the cerebellar cortex the species with larger cerebella have neurons with larger somata, and our results concur with these findings. In addition to this, our ongoing, unpublished studies on manatees, giraffes, humpback whales, Siberian tigers, clouded leopards, chimpanzees and humans indicate that the dendritic complexity of neurons increases in association with absolutely larger cerebellum size. This greater dendritic complexity in the species with larger cerebella would allow the neurons to receive information from a wider source of inputs, thus increasing the information available to the neuron prior to the cellular activity producing an action potential. The larger neurons may also possess larger and more ramifying axons, allowing the neurons to exert a broader influence within the circuit by making more contacts (with individual cells and/or aggregations of cells). This increase in dendritic complexity appears to be related to allometric scaling concomitant with absolute cerebellar size; thus, it would appear that due to scaling the larger brained mammals would have more complex cerebellar circuitry, potentially allowing for greater control over the force, extent and duration of muscular contractions. Such differences are apparent in the primate cerebral cortex, where neurons in the frontal or higher-order cortical areas show a greater dendritic complexity than those in primary or lower-order cortical areas [e.g. Jacobs et al., 2001; Elston et al., 2005a-c; Bianchi et al., 2012], and this correlates well with the complexity of neuronal information processing in these different cortical regions. Across species, in homologous cortical areas, those species with the larger cerebral cortices have neurons that exhibit greater dendritic complexity [Elston et al., 2006]. This, as with our unpublished observations on cerebellar cortical neurons, appears to be related to allometric scaling, and will allow for more complex neuronal processing to occur, thereby providing a facility for the emergence of greater behavioral sophistication without the need to resort to adaptationist rationale.

\section{Neuronal Densities in the Elephant Compared with Other Mammals}

Our stereologic assessment of neuronal densities in the cerebellum of the African elephant provided data that can be directly compared with findings reported by Lange [1975]. In his comparative assessment of cellular density across a range of mammalian species, Lange [1975] demonstrated that cell density in the cerebellar cortex of the African elephant was lower than that found in the other, smaller brained species he examined. Lange reported a density of 7,810 Purkinje cells $/ \mathrm{mm}^{3}$ in the African elephant, which compares well with our results which ranged between 5,894 and 8,812 cells $/ \mathrm{mm}^{3}$; however, his estimate of 28,880 cells $/ \mathrm{mm}^{3}$ in the molecular layer is approximately 3-4 times higher than we observed (table 3). This difference is likely to be a methodological variance and indeed Lange [1975] mentions that due to the long period between death and fixation of the tissue used for the elephant, aquatic mammals and humans, that it was not always possible to differentiate neurons from glial cells and pericytes in the molecular layer in these brains'. The better-preserved tissue used in the current study [Manger et al., 2009] leads us to believe that the current results are likely to be more accurate than those of Lange [1975]. Nevertheless, it would appear that the conclusions reached by Lange are valid, even if the exact quantification is somewhat imprecise.

Haug [1967] and Lange [1975] both consider that the elephant will have a greater volume fraction of neuropil 
Table 4. Comparative summary of the distribution of calcium-binding protein immunoreactivity in the various structures of the cerebellar cortex across a small sample of mammalian species previously studied

\begin{tabular}{|c|c|c|c|c|c|c|c|c|c|c|c|c|c|c|c|}
\hline $\begin{array}{l}\text { Species: } \\
\text { Structure: }\end{array}$ & \multicolumn{3}{|c|}{ Elephant $^{1}$} & \multicolumn{3}{|c|}{ Cetaceans $^{2}$} & \multicolumn{3}{|c|}{ Echidna $^{3}$} & \multicolumn{3}{|c|}{ Squirrel monkey ${ }^{4}$} & \multicolumn{3}{|c|}{ Laboratory rat ${ }^{5}$} \\
\hline Basket cells & ++ & ++ & - & +++ & - & - & - & - & - & +++ & - & - & ++ & - & - \\
\hline Parallel fibers & +++ & - & - & - & $?$ & - & - & - & - & - & - & +++ & - & - & +++ \\
\hline Climbing fibers & - & +++ & +++ & - & $?$ & +++ & - & ++ & ++ & ++ & - & - & - & - & - \\
\hline Granule cells & - & - & - & - & - & +++ & - & - & - & - & - & +++ & - & - & +++ \\
\hline Mossy fibers & - & - & - & - & - & ++ & - & - & - & +++ & - & +++ & - & - & ++ \\
\hline Golgi type II cells & - & ++ & - & +++ & ++ & - & - & - & - & +++ & +++ & +++ & - & - & ++ \\
\hline Lugaro neurons & - & - & ++ & - & - & - & - & - & - & - & - & +++ & - & - & + \\
\hline Unipolar brush neurons & - & - & - & - & - & +++ & - & - & - & - & - & +++ & - & - & $?$ \\
\hline
\end{tabular}

Symbols provide a qualitative impression of staining intensity, - indicates no staining, +/- indicates a mixture of positive and negative staining in the same individual. $\mathrm{PV}=$ Parvalbumin; $\mathrm{CB}=$ calbindin; $\mathrm{CR}=$ calretinin.

${ }^{1}$ This study. ${ }^{2}$ Kalinichenko and Pushchin, 2008, bottlenose dolphin and harbor porpoise. ${ }^{3}$ Ashwell et al., 2007. ${ }^{4}$ Fortin et al., 1998. ${ }^{5}$ Rogers, 1989; Celio, 1990; Résibois and Rogers, 1992.

in the cerebellar cortex than the smaller brained mammals. This observation dovetails nicely with our observations of greater dendritic complexity of individual neurons when examined with Golgi staining (see above); however, due to changes in glia:neuron ratios (larger brains have more glia per neuron) [Sherwood et al., 2006], this is not an exact fit. Therefore, the increased numbers of glia must be taken into account when theorizing on the potential advantages that having a greater volume fraction of neuropil will afford the processing of neural information. Despite this caveat, the stereologic assessment provides additional supporting data indicating that the elephant has a greater volume of a more complex cerebellar cortex to control and coordinate movement compared to many other mammalian species.

\section{Variations in Calcium-Binding Protein Expression in Mammalian Cerebellar Cortex}

As with other aspects of the elephant cerebellum, the expression of the calcium-binding proteins (parvalbumin, calbindin and calretinin) exhibited a mixture of patterns similar to those seen in other mammals, and which contrasted with some other mammals. A short survey of the expression of the three calcium-binding proteins in five mammalian species is provided in table 4: bottlenose dolphin and harbor porpoise [Kalinichenko and Pushchin, 2008], echidna [Ashwell et al., 2007], squirrel monkey [Fortin et al., 1998] and laboratory rat [Rogers, 1989; Celio, 1990; Résibois and Rogers, 1992]. The presence of parvalbumin in stellate and basket cells is a feature common to the eutherian mammals surveyed, while parvalbumin is present in the Purkinje cells of all eutherian mammals plus the prototherian echidna. The presence of calbindin in the Purkinje cells of all mammal species surveyed is also a common feature; however, it is at this point that the commonalities end.

In contrast to the other mammals surveyed, the elephant is unique in showing parvalbumin expression in the parallel fibers and calbindin expression in the stellate and basket cells. The remaining structures in which the calcium binding proteins were expressed showed a great deal of variance among the species surveyed. Parvalbumin acts as a slow buffer of calcium dynamics; calbindin shows a similar, but somewhat faster buffering action of calcium dynamics while calretinin appears to act more as a calcium modulator, showing dual kinetic properties, rather than acting as a buffer [Billing-Marczak and Kuznicki, 1999; Schmidt et al., 2003; Barinka and Druga, 2010]. These calcium transients provide short-lived and highly compartmentalized signals within the dendrites and spines of the neurons in which they are present. Thus, the differential expression pattern of the calcium-binding proteins may alter the action of the neurons forming the cerebellar cortical circuit. In the case of the elephant, 
the presence of calbindin in the stellate and basket cells may increase their excitability, whereas the presence of parvalbumin in the parallel fibers may depress repeated excitation. Although the exact effects the expressional complement of calcium-binding proteins may have on the cerebellar circuitry in the elephant or other mammals is unknown, the effects are likely to be significant. It would be of interest to undertake a broad comparative study of the expression of these proteins across mammalian species, both within and between orders, to determine whether there is phylogenetic signal in their expression within the circuitry (i.e., is the expression of these proteins similar in all rodents or all primates?), and if the differences between species provide some predictability of motor outcomes (i.e., do the differences between rodents and primates account for differences in order-typical behavioral pattern expressions?). Further data on the expression of the calcium-binding proteins across a range of species, perhaps within the context of phylogenetic analysis, may provide interesting insights into the common expression of motor patterns within closely related species.

\section{The Cerebellum and Life-History of the African Elephant}

Three aspects of central importance regarding the African elephant cerebellum and how it relates to the life of these animals have emerged from the current and previous [Maseko et al., 2012] studies: (1) the elephants have a very large cerebellum in absolute size; (2) they have the largest relative cerebellar size of all mammals examined to date, and (3) the cerebellar cortical circuitry of the elephant is likely to be more complex than in most other mammals. There are at least two aspects of sensorimotor coordination undertaken by the elephant where a large cerebellum with unique circuitry may play a crucial role. The first is in control of the trunk, an unpaired appendage that, while only consisting of a few muscles is made up of over 100,000 distinct muscle bundles [Endo et al., 2001], requires extensive learning to use effectively for environmental manipulation [Lee and Moss, 1999], is used in coordination with the eyes [Pettigrew et al., 2010] and is used for social interaction [Lee and Moss, 1999]. The second is in the control and production of infrasonic vocalizations [e.g. Garstang, 2004], for which current thinking suggests that control of the laryngeal region is of importance [Herbst et al., 2012]. These two central aspects of the behavioral biology of elephants would clearly benefit from evolutionary modifications of the cerebellum to support sophisticated output for motor control.

One question of importance that cannot be addressed here regards the evolution of the elephant cerebellum. The absolute size of the elephant cerebellum can, for the most part, be explained by allometric scaling regularities that operate across mammals [e.g. Finlay and Darlington, 1995], but the increased relative size [Maseko et al., 2012] requires a different explanation. It would be of interest to track the evolution of cerebellar size in the Proboscid ancestors of modern elephants to determine whether increased cerebellar volume appeared at a particular stage in their evolution. For example, did the relative size of the cerebellum increase when the trunk began to evolve, or when the capacity to create infrasonic vocalization evolved, or is the increased relative cerebellar size of the extant elephants an ancestral condition? Paleoneurological studies of the Proboscid brain may provide interesting and significant insights into the mechanisms and associated somatic adaptations related to the evolution of absolute and relative cerebellar volumes.

\section{References}

Ashwell KW, Paxinos G, Watson CR (2007): Cyto- and chemoarchitecture of the cerebellum of the short-beaked echidna (Tachyglossus aculeatus). Brain Behav Evol 70:71-89.

-Barinka F, Druga R (2010): Calretinin expression in the mammalian neocortex: a review. Physiol Rev 59:665-677.

Bianchi S, Stimpson CD, Bauernfeind AL, Schapiro SJ, Baze WB, McArthur MJ, Bronson E, Hopkins WD, Semendeferi K, Jacobs B, Hof PR, Sherwood CC (2012): Dendritic morphology of pyramidal neurons in the chimpanzee neocortex: regional specializations and comparison to humans. Cereb Cortex, E-pub ahead of print.

Billing-Marczak K, Kuznicki J (1999): Calretinin - sensor or buffer - function still unclear. Pol J Pharmacol 51:173-178.

Celio MR (1990): Calbindin D-28k and parvalbumin in the rat nervous system. Neuroscience 35:375-475.

Cozzi B, Spagnoli S, Bruno L (2001): An overview of the central nervous system of the elephant through a critical appraisal of the literature published in the XIX and XX centuries. Brain Res Bull 54:219-227.

\footnotetext{
Dvergsten CL, Fosmire GJ, Ollerich DA, Sandstead HH (1984): Alterations in the postnatal development of the cerebellar cortex due to zinc deficiency. II. Impaired maturation of Purkinje cells. Brain Res 318:11-20.

Elston GN, Benavides-Piccione R, Elston A, DeFilipe J, Manger PR (2005a): Specialization in pyramidal cell structure in the cingulate cortex of the Chacma baboon (Papio ursi$n u s)$ : an intracellular injection study of the posterior and anterior cingulate gyrus with comparative notes on the macaque and vervet monkeys. Neurosci Lett 387:130-135.
} 
Elston GN, Benavides-Piccione R, Elston A, DeFilipe J, Manger PR (2005b): Pyramidal cell specialization in the occipitotemporal cortex of the Chacma baboon (Papio ursinus). Exp Brain Res 167:496-503.

-Elston GN, Benavides-Piccione R, Elston A, Manger PR, DeFilipe J (2005c): Specialization in pyramidal structure in the sensorymotor cortex of the Chacma baboon (Papio ursinus) with comparative notes on macaque and vervet monkeys. Anat Rec A 286A:854865.

-Elston GN, Benavides-Piccione R, Elston A, Zeitsch B, DeFelipe J, Manger PR, Casagrande V, Kaas JH (2006): Specializations of the granular prefrontal cortex of primates: implications for cognitive processing. Anat Rec A 288A:26-35.

Endo H, Hayashi Y, Komiya T, Narushima E, Sasako M (2001): Muscle architecture of the elongated nose in the Asian elephant (Elephas maximus). J Vet Med Sci 63:533-537.

- Finlay BL, Darlington RB (1995): Linked regularities in the development and evolution of mammalian brains. Science 268:1578-1584.

Fortin M, Marchand R, Parent A (1998): Calcium-binding proteins in primate cerebellum. Neurosci Res 30:155-168.

Foster RE, Peterson BE (1986): The inferior olivary complex of guinea pig: cy toarchitecture and cellular morphology. Brain Res Bull 17: 785-800.

Gallyas F (1979): Silver staining of myelin by means of physical development. Neurol Res 1:203-209.

Garstang M (2004): Long-distance, low-frequency elephant communication. J Comp Physiol A Neuroethol Sens Neural Behav Physiol 190:791-805.

Haug H (1967): Zytoarchitektonische Untersuchungen an der Hirnrinde des Elefanten. Anat Anz Erg-H 120:331-337.

- Herbst CT, Stoeger AS, Frey R, Lohscheller J, Titze IR, Gumpenberger M, Fitch WT (2012): How low can you go? Physical production mechanism of elephant infrasonic vocalizations. Science 337:595-599.

-Ito M (2006): Cerebellar circuitry as a neuronal machine. Prog Neurobiol 78:272-303.

-Jacobs B, Driscoll L, Schall M (1997): Life-span dendritic and spine changes in areas 10 and 18 of human cortex: a quantitative Golgi study. J Comp Neurol 386:661-680.

- Jacobs B, Lubs J, Hannan M, Anderson K, Butti C, Sherwood C, Hof PR, Manger PR (2011): Neuronal morphology in the African elephant (Loxodonta africana) neocortex. Brain Struct Funct 215:273-298.
Jacobs B, Schall M, Prather M, Kapler E, Driscoll L, Baca S (2001): Regional dendritic and spine variation in human cerebral cortex: a quantitative Golgi study. Cereb Cortex 11: 558-571.

Kalinichenko SG, Pushchin II (2008): Calciumbinding proteins in the cerebellar cortex of the bottlenose dolphin and harbor porpoise. J Chem Neuroanat 35:364-370.

Lainé J, Axelrad H (1994): The candelabrum cell: a new interneuron in the cerebellar cortex. J Comp Neurol 339:159-173.

Lainé J, Axelrad H (2002): Extending the cerebellar Lugaro cell class. Neuroscience 115: 363-374.

Lange W (1971): Vergleichende Untersuchungen am Kleinhirn des Menschen, des Elefanten und einiger Zahnwale. Verh Anat Ges 65: 137-138.

Lange W (1975): Cell number and cell density in the cerebellar cortex of man and some other mammals. Cell Tiss Res 157:115-124.

Lee PC, Moss CJ (1999): The social context for learning and behavioral development among wild African elephants; in Box HO, Gibson KR (eds): Mammalian Social Learning: Comparative and Ecological Perspectives. Cambridge, Cambridge University Press, pp 102-125.

Manger PR (2006): An examination of cetacean brain structure with a novel hypothesis correlating thermogenesis to the evolution of a big brain. Biol Rev Camb Philos Soc 81:293338.

- Manger PR, Pillay P, Maseko BC, Bhagwandin A, Gravett N, Moon D, Jillani NE, Hemingway J (2009): Acquisition of the brain of the African elephant (Loxodonta africana): perfusion-fixation and dissection. J Neurosci Methods 179:16-21.

Mann DM, Yates PO (1979): A quantitative study of the glia of the Purkinje cell layer of the cerebellum in mammals. Neuropathol Appl Neurobiol 5:71-76.

Maseko BC, Spocter M, Haagensen M, Manger PR (2012): Elephants have relatively the largest cerebellum size of mammals. Anat Rec 295:661-672.

-Melik-Musyan AB, Fanardzhyan VV (2004): Morphological characteristics of Lugaro cells in the cerebellar cortex. Neurosci Behav Physiol 34:633-638.

Mouton PR (2002): Principles and Practices of Unbiased Stereology: An Introduction for Bioscientists. Baltimore, Johns Hopkins University Press.

Obersteiner H (1913): Die Kleinhirnrinde von Elephas und Balaenoptera. Arb Neurol Inst Wien 20:145-154.

Palay S, Chan-Palay V (1974): Cerebellar Cortex, Cytology and Organization. Berlin, Springer.
Pettigrew JD, Bhagwandin A, Haagensen M, Manger PR (2010): Visual acuity and heterogeneities of retinal ganglion cell densities and the tapetum lucidum of the African elephant (Loxodonta africana). Brain Behav Evol 75:251-261.

Résibois A, Rogers JH (1992): Calretinin in rat brain: an immunohistochemical study. Neuroscience 46:101-134.

Rogers JH (1989): Immunoreactivity for calretinin and other calcium-binding proteins in cerebellum. Neuroscience 31:711-721.

Scheibel ME, Scheibel AB (1978): The methods of Golgi; in Robertson RT (ed): Neuroanatomical Research Techniques. New York, Academic Press, pp 89-114.

Schmidt H, Stiefel KM, Racay P, Schwaller B, Eilers J (2003): Mutational analysis of dendritic $\mathrm{Ca}^{2+}$ kinetics in rodent Purkinje cells: role of parvalbumin and calbindin $\mathrm{D}_{28 \mathrm{k}}$. J Physiol 551:13-32.

-Sherwood CC, Stimpson CD, Raghanti MA, Wildman DE, Uddin M, Grossman LI, Goodman M, Redmond RC, Bonar CJ, Erwin JM, Hof PR (2006): Evolution of increased glia-neuron ratios in the human frontal cortex. Proc Natl Acad Sci USA 103: 13606-13611.

-Sherwood CC, Wahl E, Erwin JM, Hof PR, Hopkins WD (2007): Histological asymmetries of primary motor cortex predict handedness in chimpanzees (Pan troglodytes). J Comp Neurol 503:525-537.

-Shoshani J, Kupsky WJ, Marchant GH (2006): Elephant brain - part 1: gross morphology, functions, comparative anatomy, and evolution. Brain Res Bull 70:124-157.

Wahl D, Hof PR, Sherwood CC, Maseko BC, Manger PR, Jacobs B (2012): Comparative neuromorphology of Florida manatee, giraffe, human, and African Elephant cerebellar cortex. Poster Presentation at Rocky Mountain Regional Neuroscience Group, Aurora, Colorado.

Wen Q, Stepanyants A, Elston GN, Grosberg AY, Chklovskii DB (2009): Maximization of the connectivity repertoire as a statistical principle governing the shapes of dendritic arbors. Proc Natl Acad Sci USA 106:1253612541.

-West MJ, Slomianka L, Gundersen, HJG (1991): Unbiased stereological estimation of the total number of neurons in the subdivisions of the rat hippocampus using the optical fractionator. Anat Rec 231:482-497.

-Whitney ER, Kemper TL, Rosene DL, Bauman ML, Blatt GJ (2009): Density of cerebellar basket and stellate cells in autism: evidence for a late developmental loss of Purkinje cells. J Neurosci Res 87:2245-2254. 